\title{
EM BUSCA DO POVO. A criação do jornal Noticias Populares e a oposição ao governo João Goulart
}

\author{
Larissa Raele Cestari*
}

\begin{abstract}
RESUMO: Neste artigo, analiso a criação do jornal Notícias Populares, em São Paulo, em 1963, articulando-a à concepção de povo que orientou seus fundadores. O jornal fez parte das estratégias do empresário e líder udenista Herbert Levy de combate ao governo João Goulart (1961-1964). Levo em conta o papel que o jornal Última Hora, de Samuel Wainer, desempenhou nesse processo. Questiono a intepretação historiográfica que aponta para a função despolitizadora do Notícias Populares. Defendo a ideia do reconhecimento do povo como ator político a ser conquistado, que obrigou setores da direita a reverem suas estratégias de aproximação com as classes populares.

PALAVRAS-CHAVE: Jornal Notícias Populares; Herbert Levy; Classes populares; Governo João

Goulart.
\end{abstract}

\section{Searching for the people. The creation of the newspaper called "Noticias Populares" and the opposition to the government of the then president joão goulart.}

ABSTRACT: Here in this article, I analyse the creation of the newspaper "Noticias Populares", in São Paulo (Brazil), in 1963, and I link it to the people's conception which orientated its founders. The newspaper was part of the strategies of the entrepreneur and political leader of tbe political party UDN, his name was Herbert Levy in fighting the government of João Goulart (1961-1964). I take into account the role that the newspaper called "Última Hora" of Samuel Wainer played in this process. I question the historiographic interpretation that points to the non-political activity of the newspaper "Noticias Populares". I support the idea of the people's acknowledgement as a political actor to be achieved which compelled the Right-wing Party sectors to review their approaching strategies towards the working classes.

KEY-WORDS: Newspaper "Noticias Populares"; Herbert Levy; Working classes; João Goulart's government.

\section{Em busca del Pueblo. La creación del periódico Notícias Populares y la oposición al gobierno João Goulart}

RESUMEN: En este artículo analizo la creación del periódico Notícias Populares, en São Paulo, en 1963, relacionándola a la concepción de "pueblo" que orientó a sus fundadores. El periódico era parte de las estrategias del empresario y líder udenista Herbert Levy para confrontar al gobierno de João Goulart (1961-1964). Considero el papel que el periódico Última Hora, de Samuel Wainer, desempeñó en este proceso. Cuestiono la interpretación historiográfica que señala una función despolitizadora de Notícias Populares. Defiendo la idea del reconocimiento del pueblo como actor político a ser conquistado, lo que obligó a sectores de la derecha a revisar sus estrategias de aproximación a las clases populares.

PALABRAS CLAVE: Periódico Notícias Populares; Herbert Levy; Clases populares; Gobierno João Goulart.

\footnotetext{
*Mestre em História pelo Centro de Pesquisa e Documentação de História Contemporânea do Brasil. Atualmente é doutoranda em História pelo programa de Pós-graduação em História da Universidade Federal de Juiz de Fora. Contato: Rua José Lourenço Kelmer, s\n, Campus Universitário, São Pedro, CEP: 36036-900, Juiz de Fora-MG, Brasil. E-mail:larissacestari@uol.com.br. ORCID: https://orcid.org/0000-0002-5637-4461
} 
O jornal Notícias Populares, publicado em São Paulo, entre 1963 e 2001, ficou marcado na memória dos paulistas como um jornal de escândalos, com manchetes sensacionalistas, ao lançar mão da fórmula "sexo, crime e esportes" para atrair leitores das classes populares. É praticamente desconhecido o sentido político da sua criação, em 1963, por Herbert Levy, proeminente empresário e líder udenista. Notícias Populares fez parte de um trabalho de contraofensiva política ao governo João Goulart (1961-1964) cujo parâmetro foi a disputa pelo povo ${ }^{1}$.

Neste artigo, analiso o processo de criação e montagem do Notícias Populares, articulando-o à concepção de povo e de jornal popular que orientou seus criadores. O objetivo é trazer elementos que ajudem na compreensão do significado que Herbert Levy imprimiu às classes populares no âmbito da luta política da primeira metade dos anos de 1960.

Levo em conta o papel que o jornal Última Hora/São Paulo, de Samuel Wainer, desempenhou na fundação do Notícias Populares. Segundo Gisela Goldenstein, Notícias Populares foi criado para roubar o público do Última Hora. O jornal de Wainer era percebido como um importante instrumento de politização das classes populares, vale dizer, de seu engajamento nas propostas defendidas pelo presidente da República. Entretanto, segundo a autora, Herbert Levy não pretendia obter o apoio das classes populares às suas ações contra João Goulart, mas apenas despolitizá-las. Apoio, os setores liberais representados por Levy buscariam nas classes médias, pois somente a elas reconheceriam atributos de cidadania política $^{2}$.

Por isso a proposta de Notícias Populares, segundo Goldenstein, era ser um jornal político, mas que não trataria de política. O recurso ao sensacionalismo era entendido como o caminho mais eficaz para o seu projeto político. O trio "sexo, crime, esportes" seria a expressão de um liberalismo oligárquico incapaz de reconhecer as classes populares como um interlocutor legítimo, bem como uma forma de excluí-las da cena política ${ }^{3}$. O trabalho de Goldenstein é a referência principal das análises sobre a origem do jornal Notícias Populares.

Questionando essa interpretação, procuro mostrar, ao longo deste artigo, que a criação de Notícias Populares indicou uma outra postura de Herbert Levy em relação às classes populares. A análise da criação e montagem de Notícias Populares, bem como da sua visão de povo, permite reavaliar a interpretação de Goldenstein e questionar até que ponto, em um contexto de forte ascensão política popular, como o do início dos anos de 1960, era possível manter as classes populares fora do jogo político. Será que ao perceberem a inevitabilidade da participação popular, os segmentos representados por Herbert Levy não teriam mudado a 
estratégia para uma política de cooptação e busca de apoio popular? Nesse sentido, este artigo também contribui para o debate sobre a questão da incorporação política das classes populares, tema candente da experiência democrática de 1945 a 1964.

Vale destacar que Notícias Populares é aqui analisado como objeto da história política. Sigo a linha interpretativa de René Remond e entendo a política como a atividade que se relaciona com a conquista, o exercício e a prática do poder e as atividades a ele relacionadas. A imprensa é uma delas; afinal os "meios de comunicação não são, por natureza, realidades políticas, mas podem tornar-se políticos em virtude da sua destinação"4. Notícias Populares foi um jornal essencialmente político. Sua existência esteve relacionada às disputas políticas correntes no país, à luta pela conquista e prática do poder.

Em termos metodológicos, proponho uma caracterização geral do Notícias Populares, o que implica analisar, entre outros, os motivos e as intenções de sua criação; os nomes envolvidos no empreendimento; a tiragem; a forma como o jornal chegava às mãos dos leitores; o projeto gráfico; a forma de apresentação e distribuição dos conteúdos; a linguagem utilizada; e o tipo de relação que mantinha com o mercado jornalístico ${ }^{5}$. Esses aspectos são importantes, pois contribuem para a compreensão da linha editorial do Notícias Populares ao explicitar o projeto político que orientou seus propugnadores e o lugar das classes populares nesse projeto.

\section{Notícias Populares x Última Hora}

A ideia da criação do jornal Notícias Populares partiu do jornalista romeno, exilado no Brasil, Jean Mellé. Na Romênia, Mellé, foi proprietário de um dos jornais mais populares do país chamado Momentul. Quando, em 1947, o exército soviético ocupou a Romênia, Mellé fez oposição ao novo sistema e foi preso após publicar a manchete "Russos roubam o pão do povo". Depois de dez anos na Sibéria, foi libertado em 1958. No ano seguinte, buscou exílio no Brasil e foi contratado por Samuel Wainer para trabalhar como colunista internacional do jornal Última Hora, edição paulista ${ }^{6}$.

No final do ano de 1962, assustado com o "perigo comunista" que acreditava assolar o Brasil, Mellé deixou a redação do Última Hora, que, na sua visão, caminhava cada vez mais à esquerda, para dedicar-se à elaboração de um jornal popular anticomunista, nos moldes do antigo Momentul, sonho que nunca tinha abandonado ${ }^{7}$. A volta do regime presidencialista, em janeiro de 1963, facilitou a realização desse sonho. Foi quando Mellé procurou Herbert Levy, 
então presidente nacional da União Democrática Nacional (UDN), e um dos líderes da oposição do empresariado paulista ao governo Goulart.

Herbert Levy era dono de um conglomerado econômico que envolvia atividades relacionadas ao capital financeiro, agrícola e comercial. Na conjuntura do início dos anos de 1960, atuava de diferentes formas no combate ao governo de João Goulart e à influência dos grupos de esquerda na mobilização dos trabalhadores. Destacava-se como um dos líderes da oposição liberal ao governo Goulart, formando, na UDN, o grupo de direita chamado "banda de música". Como deputado federal desde 1947, integrava a Ação Democrática Parlamentar, bloco interpartidário que fazia oposição intransigente às propostas do governo e das esquerdas, entendidas como comunistas. Também compunha o grupo paulista do Instituto de Pesquisa e Estudos Sociais (IPES), participando, desde 1963, de reuniões conspiratórias com políticos e militares para derrubar João Goulart ${ }^{8}$.

Quanto à mobilização dos trabalhadores, para contrabalançar a força da esquerda em meio aos operários, Levy apoiava sindicatos anticomunistas, como o Movimento Sindical Democrático (MSD), criado em maio de 1961. Sua atuação junto às classes populares, no entanto, teve início em 1958, quando participou da organização das "caravanas da liberdade", visando conquistar eleitores do povo. Segundo Benevides, esse "aceno populista da UDN" significou apenas uma mudança de tática, dada a centralidade do voto nesse período, pois, na essência, o partido manteve a visão elitista quanto "às questões cruciais da sociedade, sobretudo do ângulo dos interesses das classes populares"9.

No encontro com Herbert Levy, Jean Mellé avisou que o assunto era de "segurança nacional" e expôs seu projeto de criação de um jornal popular, cujo objetivo seria roubar o público do Última Hora para impedir que o seu discurso chegasse às classes populares. Mellé alertou que Última Hora, periódico identificado com as posições do Partido Trabalhista Brasileiro (PTB), exercia um papel perigoso no jogo político da época, pois, em meio a suas notícias, que considerava "sensacionalistas", difundia mensagens da esquerda ao promover a politização das classes populares e o apoio ao governo de João Goulart ${ }^{10}$.

Lançado por Samuel Wainer, em 1951, no Rio de Janeiro, Última Hora, embora fosse voltado para um público policlassista, dedicou-se, conforme mostra Carla Siqueira, especialmente às classes populares. O objetivo do jornal era ser porta-voz da política getulista, especialmente do trabalhismo e do nacionalismo, reforçando os laços entre Vargas e as classes trabalhadoras. Para atingi-lo, Wainer utilizou as técnicas de sedução do público com a exploração de temas sensacionalistas, os quais, no entanto, ficaram limitados a 
determinados espaços do jornal - na capa, na contracapa e nas editorias de polícia, esportes e cidades. Campanhas nacionalistas e temas de reivindicação social eram articulados a temas considerados do gosto popular como "sexo, crime e esportes". Última Hora assumiu, também, uma "postura de intermediário entre o povo e o governo, prestando serviços efetivos e importantes como nas queixas dos leitores e aconselhamento em relação às questões trabalhistas" $" 11$.

Como mostra Goldenstein, as técnicas da indústria cultural, voltadas para um público policlassista, foram adaptadas aos objetivos políticos do jornal que passou a apresentar um conteúdo diverso capaz de atender aos diferentes tipos de interesses. Notícias políticas e econômicas eram misturadas a colunas sociais, faits-divers, esportes, polícia, colunas de crítica literária, de cinema, de artes plásticas, entre outros. Vale destacar que Última Hora também inovou ao adotar uma diagramação moderna com paginação acessível, coberturas fotográficas, valorização de notícias através de jogos de espaços e fotos, o que facilitava a leitura e fazia com que o jornal se apresentasse de maneira mais fácil, sem o ar da imprensa tradicional $^{12}$.

Ainda em 1951, Vargas sugeriu a Samuel Wainer a criação de uma sucursal em São Paulo, onde o PTB, segundo Benevides, não conseguia capitalizar inteiramente a popularidade de Vargas entre os trabalhadores, sendo um partido fraco eleitoralmente e tendo que disputar com outras correntes o movimento sindical ${ }^{13}$. A edição paulista de Última Hora deveria ser um instrumento para a afirmação da relação de Vargas e do PTB com as classes trabalhadoras no principal centro industrial do país.

Assim, em março de 1952, surgiu o Última Hora de São Paulo, que passou a contar com duas edições diárias, uma matutina e outra vespertina. Em pouco tempo, o novo jornal tornou-se o periódico mais vendido em São Paulo, superando O Estado de S. Paulo e Folha de S. Paulo, tradicionalmente os veículos mais importantes desse estado ${ }^{14}$.

No entanto, o discurso de Última Hora, no que buscava o apoio popular a Getúlio Vargas, somado ao sucesso comercial do jornal junto a esses leitores, despertou a oposição de setores liberais udenistas. Nesse sentido, não foi por acaso que a Comissão Parlamentar de Inquérito contra Última Hora, promovida pela oposição liberal em 1953, com apoio de Herbert Levy, coincidiu com os ataques udenistas à política trabalhista de Vargas, especialmente durante o período em que João Goulart ocupou a pasta do Trabalho.

O relacionamento de Goulart, herdeiro político de Vargas, com as classes trabalhadoras, que o jornal Última Hora ajudou a construir, teria sido, a meu ver, o principal 
motivo para o apoio que Herbert Levy deu à sugestão de Mellé para fundar o jornal Notícias Populares. As classes populares eram vistas por Herbert Levy como o principal apoio político das ações do governo João Goulart.

A percepção do perigo que Última Hora representava foi acentuada no início da década de 1960, quando a polarização política e ideológica do período influenciou a própria linha editorial do jornal. Última Hora passou a defender e a acompanhar a radicalização das teses das esquerdas, especialmente do PTB, e se incorporou ao esquema de sustentação do governo Goulart. Segundo Wainer, o jornal nunca foi comunista, mas "houve momentos em que Última Hora pareceu favorável à execução de reformas perigosamente ousadas, ou até mesmo à consumação de um golpe de esquerda"15.

Em outubro de 1963, após o episódio da tentativa fracassada de aprovação do estado de sítio, Última Hora conclamou o governo a não perder suas bases de apoio entre as classes populares, e nem protelar as reformas de base, o que implicava, necessariamente, propor alterações na Constituição. Última Hora atribuía, ainda, as denúncias de "comunização do Brasil" a setores retrógrados, compostos por "udenistas aliados ao capital estrangeiro", que se opunham à implementação de reformas no país e articulavam um golpe contra o governo. Títulos como Povo unido conquistará reformas ${ }^{16}$ ou Constituição está superada ${ }^{17}$ eram recorrentes no jornal.

É fácil entender por que Última Hora tornou-se um alvo importante a ser combatido. Na visão de Levy, após o êxito do plebiscito e o retorno do presidencialismo, no início de 1963, “[...] Última Hora, sob a direção de Samuel Wainer, passou a ser um instrumento escancarado para ganhar terreno popular."18.

\section{A polarização e a radicalização}

Trabalho com a ideia de que, a partir da crise de $1961^{19}$, quando a tentativa de oposição à posse do então vice-presidente João Goulart foi impedida pela resistência de amplos setores da sociedade civil, com destaque para a mobilização das classes populares, tornou-se claro, para Herbert Levy, que intervenções no processo político brasileiro, a partir daquele momento, só poderiam ser realizadas se contassem com o apoio dessas classes. Essa percepção foi acentuada após o crescimento eleitoral do PTB, em 1962, e o retorno do presidencialismo, em 1963. 
O PTB, que tinha sua base eleitoral nas classes populares urbanas, quase dobrou sua representação na Câmara dos Deputados, tornando-se a segunda força no parlamento, superando a UDN. A campanha pela antecipação do plebiscito, marcada por greves e manifestações populares, bem como a vitória do presidencialismo, após o comparecimento em peso do eleitorado, fez com que os grupos de esquerda começassem a apostar, cada vez mais, na mobilização das classes populares. Por meio de ações políticas extrainstitucionais como manifestações de rua, comícios e greves políticas, pressionavam o Congresso a aprovar as reformas de base. Além disso, em um contexto democrático, em que a classe trabalhadora adquiria peso eleitoral, a conquista de uma base popular tornava-se condição sine qua non para a conquista ou preservação do poder. A meu ver, esses fatores serviram de pedagogia política ao grupo de Levy. A participação política popular foi vista como um ponto de não retorno. A partir dali, Herbert Levy passaria a disputar as classes populares com os grupos de esquerda.

Em entrevista dada a Gisela Goldenstein, em 1974, Luis Fernando Levy, filho de Herbert Levy que ficou responsável pela administração do jornal Notícias Populares, mostrou como o governo Goulart foi percebido pelo seu grupo, e de que modo seus membros atuaram naquele período:

"[...] Quando Goulart assumiu, houve aquela degringolada e rapidamente alguns grupos começaram a influir decisivamente junto a ele: [...] grupos interessados em esquerdizar radicalmente a posição do governo brasileiro [...] No início de 1963 [...] nós, dentro da linha que vínhamos seguindo, resolvemos atuar em todos os campos no sentido de impedir que o caos tomasse conta das coisas e que os grupos ligados tanto ao radicalismo de esquerda quanto aos corruptos que se aproveitavam do poder - e que estavam associados no processo de mudança da situação - alcançassem seus objetivos., ${ }^{20}$.

Conforme assinala Goldenstein, se no discurso de Luis Fernando Levy estão presentes o elemento moral - "os corruptos que se aproveitam do poder" - e o político - "a esquerda que conseguiu influência decisiva no governo Goulart" -, na prática, a ação concreta visava mais a esquerda que a corrupção. Segundo a autora, "o alvo das ações era o movimento sindical 'dirigido', a reforma agrária, o movimento estudantil, na medida em que significavam esquerdização. Foi aí que se concentrou o fogo" ${ }^{\text {21 }}$.

Ao mesmo tempo, ao afirmar que "aprendemos a lição", Luis Fernando Levy mostra como, em um contexto de fortalecimento das esquerdas e ampliação da participação política popular, os setores udenistas e do empresariado paulista representados por Herbert Levy, em 
busca de eficácia política, reorientaram suas estratégias de ação e passaram a atuar no mesmo campo do adversário, o que incluía a adoção de táticas de mobilização popular.

Nesse sentido, a proposta de Mellé de fazer uma contraofensiva à atuação de Última Hora foi ao encontro dos interesses de Herbert Levy que, naquele momento, atuava de diferentes formas no combate ao governo de João Goulart e à influência dos grupos de esquerda na mobilização dos trabalhadores. Segundo Luis Fernando Levy:

"[...] A ideia de fazer Notícias Populares nasceu quando, neste trabalho de contraofensiva, nós verificamos que um dos instrumentos de ação perigosos, porque pegavam uma população desprevenida e desorientada no sentido de formação de opinião, era o Última Hora, que, em São Paulo, tinha cerca de uns duzentos mil jornais de tiragem e que, ao lado da alimentação, vamos dizer, que davam para o povo - que era sexo, crime, sindicatos - jogavam ideias, distorciam fatos, enfim dirigiam a opinião da população e dos trabalhadores, através desse órgão de comunicação. Nós, em contrapartida, não tínhamos o acesso, não só porque, na verdade, o sistema de comunicação com o povo é sempre mais complicado e mais difícil, como também porque nós não tínhamos aquilo que eles queriam 'beber', que era um jornal popular.[...]”22.

Assim, para Herbert Levy, o perigo de Última Hora estava tanto na eficácia da forma da sua mensagem que, por meio da fórmula "sexo, crime, sindicato", promovia a politização das classes populares, quanto no despreparo atribuído aos seus leitores que, como assinala Goldenstein, eram considerados "vitimas ignorantes e indefesas a receber, inadvertidamente, junto com a alimentação que desejavam, ideias e fatos distorcidos." 23 . Perigo estava também no fato de os "jornais liberais e conservadores fieis à democracia terem pouca penetração na área popular" ${ }^{24}$, deixando livre o mercado de jornais populares paulista para a atuação de Última Hora. Levy, por exemplo, era proprietário do jornal Gazeta Mercantil, voltado para assuntos financeiros e para leitores da elite paulistana.

Além disso, diferente do Rio de Janeiro, em que jornais como A Luta Democrática, de Tenório Cavalcanti, ou O Dia, de Chagas Freitas, disputavam o mercado da imprensa popular com o jornal Última Hora, em São Paulo, esse mercado era praticamente monopolizado pela Última Hora. O concorrente mais próximo era o jornal Diário da Noite, publicação dos Diários Associados, de Assis Chateaubriand, que, no entanto, não estava a serviço de uma determinada postura política, mas agia ao sabor das circunstâncias. Outros jornais que circulavam no mercado editorial da imprensa popular em São Paulo eram $O$ Esporte e $A$ Gazeta Esportiva, ambos voltados para a área de esportes. O Dia também circulava em São Paulo, mas sua vendagem era irrisória, não podendo ser considerado um concorrente para o 
Última Hora ${ }^{25}$. Assim, do acordo entre Levy e Jean Mellé, nasceu o jornal Notícias Populares.

\section{A montagem do jornal}

Em 19 de abril de 1963, foi criada a Editora Notícias Populares S.A., mas a montagem da estrutura do novo jornal levou alguns meses e a primeira edição só saiu em 15 de outubro daquele ano. Levy tornou-se o proprietário e delegou a administração ao seu filho, Luis Fernando Levy. Jean Mellé tornou-se o editor-chefe. A organização empresarial do jornal, no início, foi precária e marcada pela improvisação, com a utilização de oficinas e equipamentos do Gazeta Mercantil, provavelmente porque a vendagem interessava mais na medida em que faria chegar a mensagem de Notícias Populares às classes populares do que a lucratividade.

Os recursos financeiros para a criação de Notícias Populares vieram quase na totalidade de Herbert Levy. Como esperado, o empreendimento foi deficitário, apesar da boa vendagem. Poucas empresas fizeram anúncios no jornal. No entanto, não podemos deixar de notar o apoio inicial, em forma de contribuição financeira, de empresários paulistas como José Ermírio de Moraes Filho (Grupo Votorantim) e João Arruda (proprietário da tecelagem Santana $)^{26}$, que indicava a necessidade que esse setor sentiu de tirar as classes populares da influência dos grupos de esquerda. Por isso o seu apoio à criação de um jornal popular que fizesse um "fogo de encontro" ao Última Hora.

A divulgação do Notícias Populares foi feita à base de pichação de muros, lugar de tradicional difusão de mensagem dos candidatos de esquerda. Para reforçar o apelo popular, chegou às bancas por um preço mais baixo do que o da concorrência. Enquanto Última Hora custava 30 cruzeiros, Notícias Populares saía por 20. O horário de circulação também foi pensado estrategicamente: o jornal saia à noite, mas com data do dia seguinte, para que, pela manhã, quando os trabalhadores seguissem para o trabalho, já o encontrassem à venda, antes de Última Hora. Era vendido tanto nas bancas quanto por “jornaleiros ambulantes”. Segundo Goldenstein ,"nas bancas em que fosse possível, o jornal deveria ser mantido mesmo que não vendesse, de modo a fazer o público leitor acostumar-se com sua presença"27. Outra estratégia foi fazer a cobertura dos acontecimentos dos bairros populares paulistanos, colocando-os na capa do jornal. Em pouco tempo a tiragem começou a subir vertiginosamente. De 20 a 30 mil exemplares em novembro de 1963 , passou para 70 a 90 mil em agosto de $1964^{28}$.

O público visado era as classes populares urbanas, tanto o operariado quanto as camadas inferiores de assalariados não industriais e trabalhadores autônomos. Pesquisa 
realizada pelo Ibope, no período, mostrou que Notícias Populares vendia essencialmente nas "zonas 3 e 4" da cidade de São Paulo, que correspondiam, respectivamente, a "bairros de classe média e pobre" e "bairros pobres". Última Hora, embora vendesse também nas zonas 1 e 2, respectivamente, "bairros de classe rica" e "bairros de classe média e rica", zonas que Notícias Populares não atingia, vendia mais nas zonas 3 e $4^{29}$. Era nessas áreas que Notícias Populares pretendia disputar o público com Última Hora.

Interessante observar o índice de identificação partidária pré-64, pois ele ajuda a mapear o quadro político em que Levy se movimentava e entender algumas de suas escolhas e estratégias políticas. Em São Paulo, o PTB tinha, nas classes A e B, uma taxa de identificação de 10\%; na classe C, 19\%, e na classe D, 25\%. Já a UDN tinha, nas classes A e B, uma taxa de identificação de $14 \%$, na classe C, $5 \%$ e na classe D, 7\%. No entanto, a taxa de eleitores, na classe $C$, que não se identificava com nenhum partido era de $48 \%$, enquanto na $\mathrm{D}$, era de $42 \%{ }^{30}$. Esses dados revelam um grande contingente de trabalhadores que estavam abertos para serem conquistados e disputados por diferentes correntes políticas. Mais um motivo para o interesse de Levy pelo Notícias Populares.

A tarefa de montagem da equipe do jornal coube a Jean Mellé que, pagando salários maiores, "roubou" uma grande parte dos jornalistas do Última Hora, experientes na imprensa popular. É o caso de Narciso Kalili, secretário de redação, e Ramão Gomes Portão, da editoria de polícia. Na equipe do jornal: Cícero Leonel (chefe de reportagem), Sílvio Sena (editorchefe), Carlos Tavares, Sérgio Pompeu e Mauro Santayana (redatores); Dalmo Pessoa, Vital Battaglia, Rui Falcão, Adriano Neiva, Tão Gomes Pinto e Celso Brandão (esporte); Percival de Souza e José Carlos Bittencourt (geral); Fábio Mendes (correspondente de Brasília); Radu Henry, filho de Mellé (correspondente em Paris) ${ }^{31}$.

Entre os colunistas havia gente de renome, como Nelson Rodrigues, com a coluna diária "A vida como ela é". O próprio Mellé tinha coluna diária, a "Jean Mellé Informa”, sobre política nacional e internacional, cujo eixo era o forte conteúdo anticomunista.

Outro colunista importante foi o jovem jornalista Waldo Claro que, no período, era presidente da Aliança Democrática Brasileira (ADB). A ADB era uma organização de direita, formada por jovens estudantes de classes média e alta. Seu programa de ação visava combater a "comunização" nos meios estudantis, as reformas propostas por Brizola e Goulart, a legalização do PCB, a UNE e a UBES, o preenchimento de postos-chave da administração com elementos considerados comunistas, a influência de líderes sindicais nos assuntos do 
país. Por meio de sua coluna diária "Waldo Claro denuncia", situada, estrategicamente, na página sindical, Waldo Claro alertava sobre a "infiltração comunista” no Brasil.

\title{
A linha editorial do Notícias Populares
}

Segundo Gisela Goldenstein, a intenção de Notícias Populares de "roubar" o público de Última Hora não era buscar o apoio dos trabalhadores para as mobilizações contra João Goulart, mas sim a sua despolitização. Apoio, o grupo de Levy buscaria nas classes médias. Teria sido para elas que dirigiu a campanha da imprensa, buscando formar uma opinião pública mobilizada contra o governo Goulart. Sobre as classes populares, diz Goldenstein, apesar de temê-las mais do que nunca, continuava a negar-lhes cidadania política. Por isso o projeto de criação de Notícias Populares definia que o noticiário político deveria ser mínimo. Seus criadores acreditavam que, se as classes populares liam Última Hora, o faziam não pelo seu conteúdo político, mas pelo entretenimento e pelas notícias sensacionalistas. Dessa forma, em seu projeto inicial, Notícias Populares deveria se assemelhar a Última Hora, mas sem a parte política $^{32}$. Segundo Luiz Fernando Levy:

\begin{abstract}
“A fórmula sexo-crime-sindicato não é nenhuma invenção nossa. É, na verdade, o resultado de pesquisas que se faziam e era isso que levava o pessoal a comprar o jornal. Junto com isso é que vinham os outros ingredientes em Última Hora. O objetivo do jornal era, claramente, roubar o público de Última Hora. Era dar pelo menos uma alternativa, senão uma substituição, que era o que nós desejávamos e que aconteceu; nós queríamos trazer uma alternativa para fazer um fogo de encontro. [o jornal Notícias Populares] falava pouquíssimo de política, o mínimo necessário: às vezes dava cobertura a uma ou outra manifestação, dentro daquela linha de contra-ofensiva ao trabalho de desordem [...] e dar aquilo que eles estavam querendo e mais alguma coisinha água com açúcar, às vezes algumas informações [...] mas com muito cuidado e com muito critério para que não cometêssemos o erro de querer dar para nosso leitor aquilo que ele não estava nem com vontade de ler [...]"'[grifos meus] $]^{33}$.
\end{abstract}

Assim, o jornal Notícias Populares deveria ser estruturado para neutralizar a ação do jornal Última Hora sem, no entanto, polemizar com o rival. Seria um jornal político, mas que falaria o mínimo possível de política e que teria na linguagem e na temática sensacionalistas o seu carro-chefe. Essa postura dos criadores de Notícias Populares expressaria, segundo a autora, uma visão sobre as classes populares próxima à ideia de que "o povo não pensa e nem tem interesse nisso". Expressaria, também, o desejo de tirar as classes populares da influência das esquerdas e, ao mesmo tempo, evitar que elas participassem de qualquer outra forma ${ }^{34}$.

No entanto, ao confrontar o depoimento de Luiz Fernando Levy com o discurso de Notícias Populares, percebemos que, em meio ao sensacionalismo, o jornal investiu no 
noticiário político, sinal de que a participação dos trabalhadores no cenário brasileiro foi percebida em um ponto de não-retorno ${ }^{35}$. As classes populares teriam que ser reconhecidas como interlocutor/ator político. A própria presença de Levy em manifestações políticas ao lado de líderes sindicais, revelam essa percepção.

Assim, se Notícias Populares pretendia anular a atuação do Última Hora, teria de abordar os temas políticos por meio de um discurso alternativo ao do concorrente. E assim o fez. Nos primeiros meses de Notícias Populares, entre outubro e dezembro de 1963, o noticiário político, centrado na deslegitimação do governo Goulart e das esquerdas, paralelamente à promoção de Herbert Levy e da UDN, predominou no jornal, ocupando seis das suas 12 páginas. A partir de dezembro, as editorias de polícia, esportes e cidades tiveram seus espaços ampliados, por decisão de Mellé, que pretendia, com isso, aumentar a vendagem do jornal. Entretanto, o noticiário político continuou sendo pauta importante e ocupou, sozinho, entre quatro e cinco páginas do Notícias Populares.

As posições da UDN e de Herbert Levy pautaram o noticiário político. Levy foi ponto frequente no jornal, ocupou as colunas, gerou notícias, fotos, elogios. Aparecia sempre como protagonista dos acontecimentos. Denunciava o perigo da infiltração comunista no Brasil, os "planos golpistas" de João Goulart, e se posicionava como opositor intransigente do governo na defesa do povo e da democracia. Títulos como "Levy: Jango atrasa mínimo para fazer revolução",36 ou "Levy: nenhum acordo com Goulart"37 davam o tom dessa editoria.

Não por acaso, o jornal empreendeu a tarefa de construção da imagem política de Levy. Como exemplo dessas iniciativas, estavam as diversas matérias publicadas por Notícias Populares em que o empresário e político udenista pedia urgência na aprovação da escala móvel de salários, que propunha aumentos semestrais com base nos índices da inflação do país. O objetivo de Levy era disputar com o PTB a autoria do projeto e retirar essa bandeira das esquerdas. No dia 19 de novembro de 1963, Notícias Populares publicava:

\footnotetext{
“O presidente João Goulart enviará hoje mensagem ao Congresso, determinando a revisão do salário mínimo duas vezes por ano [...] Esta é uma vitória da UDN, pois representa antiga reivindicação do partido[...] Coube ao deputado Herbert Levy pedir urgência para a votação do projeto que institui o salário móvel, o qual, uma vez aprovado virá solucionar os problemas salariais [...]" [grifos meus] $]^{38}$.
}

A defesa do projeto de escala móvel de salários era um importante instrumento de expansão partidária e eleitoral. Havia uma forte rivalidade entre a UDN e o PTB, ambos interessados em apadrinhar a proposta. Além disso, o PTB não poderia renunciar à autoria de 
um projeto de alcance trabalhista. Nessa disputa, Última Hora também deu o seu recado:“ [...] Surpreendentemente, tão logo foi anunciada a disposição do governo de apresentar aquela proposição [salário móvel], os elementos oposicionistas [...] tratam de reviver o projeto que trata do mesmo assunto, apresentado já em 1951 [...]”39.

O posicionamento de Última Hora reforça a ideia sobre a importância estratégica da criação do Notícias Populares na luta política do período. É importante ressaltar que o golpe não foi a única opção de Levy para derrotar Goulart. Ele investiu, ao mesmo tempo, na manutenção do calendário eleitoral, ao promover forte campanha em torno do nome de Carlos Lacerda para a presidência da República, além de ser ele próprio um nome de peso para sucessão ao governo de São Paulo. Como diz Fico “[...] enfraquecer o governo, bloquear quaisquer eventuais pretensões continuístas do presidente e torná-lo um eleitor fraco na campanha presidencial de 1965 eram alternativas admissíveis para personagens que, depois, optariam definitivamente pelo golpe" 40.

Em suas páginas, Notícias Populares desenvolveu, ainda, uma verdadeira pedagogia política anticomunista a fim de combater o proselitismo dos grupos de esquerda. O objetivo era fornecer ideias, imagens e valores de uma tradição anticomunista, que conformasse a visão de mundo das classes populares e estimulasse o medo e a insegurança em relação ao comunismo, identificando esse perigo no governo Goulart ${ }^{41}$. Para garantir o sucesso de sua campanha, os jornalistas adotaram a estratégia de manter o assunto em evidência. Publicavam, quase diariamente, textos criticando o comunismo, de modo a fixar no público as suas mensagens ${ }^{42}$. Ao mesmo tempo, por meio de Notícias Populares, o grupo de Levy convocava a população para se juntar à "luta democrática dos udenistas" contra a subversão. No dia 16 de janeiro de 1964, por exemplo, o jornal estampava a manchete: Bilac Pinto: vamos armar o povo contra a subversão. Dessa forma, buscava o apoio popular para a estratégia do líder udenista que denunciava uma suposta "guerra revolucionária" em curso no Brasil e legitimar as ações que a direita preparava contra o governo Goulart.

Notícias Populares também disputou o tema das reformas de base. O objetivo era tirar essa bandeira de João Goulart e das esquerdas, a fim de anular um provável apoio que o governo poderia obter das classes populares com essas propostas. A UDN aparecia nas páginas do jornal como propositora de reformas cristãs e democráticas. O projeto de lei de reforma agrária do deputado udenista Milton Campos, recusado pelo PTB, no Congresso, era apresentado como um exemplo do empenho desse partido na solução do problema e, ao mesmo tempo, prova de que o Presidente da República e seu partido não tinham interesse real 
no tema. Na publicação de entrevista dada por Herbert Levy, em novembro de 1963, o jornal destacava que, se não fosse pela recusa do PTB, a reforma agrária proposta pela UDN "poderia estar em plena execução, minorando dos problemas do campo"43.

Isso mostra, portanto, a necessidade de reavaliar a interpretação de Goldenstein e questionar até que ponto era possível manter as classes populares fora do jogo político. Ao mesmo tempo, o reconhecimento do povo como sujeito político, ideia defendida neste artigo, não foi feito sem tensões. Embora considerado ator político de peso, que deveria ser conquistado, continuava sendo visto como despreparado intelectualmente para agir e pensar por si mesmo, já que sua ação política era atribuída a manipulações dos grupos de esquerda.

\section{A concepção de povo do jornal Notícias Populares}

A visão de "povo" compartilhada por setores udenistas e do empresariado paulista apareceu na linha editorial do jornal, sob a responsabilidade de Jean Mellé. A tarefa de Mellé seria adequar a linguagem e o discurso de Notícias Populares às características culturais que ele supunha ser dos seus leitores. Na sua visão, para que houvesse eficácia no convencimento dos leitores, os jornalistas deveriam trabalhar com temas que fossem sensíveis às classes populares, relacionados, portanto, ao seu universo simbólico.

A fórmula encontrada foi mesclar elementos tradicionais da imprensa sensacionalista, que ele acreditava ser o chamariz para os leitores, com temas políticos contemporâneos. Apostando que o leitor popular compra jornal por impulso, Mellé fez da manchete de Notícias Populares e da primeira página o carro-chefe do jornal ${ }^{44}$. Assim, a primeira página do dia 10 de março de 1964 trazia como manchete, Aluguéis: JG assina lei no dia 13. E como títulos: Bacanal na rua Clélia: janelas abertas; Preso Miguelito rei dos impalas; OEA: Cuba faz agitações no Brasil; PUC: mais 2.000 em greve; Óleos e ovos subiram; Brejão: líder quer 1 bilhão pelas terras; De Gaulle vai falar espanhol; Pivetes presos dormindo.

Neste ponto, é interessante retomar algumas considerações sobre o sensacionalismo, pois foi recorrendo a ele que Mellé buscou forjar a identificação do jornal com o público. Segundo Marialva Barbosa, a fórmula sensacionalista está baseada no enquadramento dramático (trágico ou cômico) dado à notícia que, ao mesclar realismo e romance e superdimensionar os acontecimentos, apela às sensações que provocam emoção pela proximidade com o fato reconstituído. A edição fantasiosa característica da narrativa sensacional é apresentada dentro de parâmetros de verossimilhança. O leitor deve reconhecer, na trama, um mundo romanceado, que não pode ser encarado sem a carga de ficcionalidade, 
mas, ao mesmo tempo, real; caso contrário, perde a credibilidade diante do leitor. Além disso, o texto sensacionalista apela a valores duais, carregados de ensinamentos morais, como a ideia do mal contra o bem. Tudo isso narrado sob a forma de um melodrama cotidiano ${ }^{45}$.

As chaves do jornalismo sensacionalista estariam, ainda, na intensificação e exagero gráfico, temático, linguístico, com o abuso das ilustrações e fotografias e temas que valorizam um conteúdo melodramático centrado, na maioria das vezes, na violência. A linguagem informal e irreverente, baseada em imagens e pobre em conceitos, é, ao lado da valorização das manchetes que buscam o insólito e a extravagância dos fait-divers, outra característica desse tipo de jornalismo. Os títulos são seguidos por subtítulos que resumem o drama e facilitam a leitura de um público que se considera ter pouco hábito de leitura ${ }^{46}$.

Todos esses elementos estiveram presentes, em maior ou menor grau, dependendo da seção do jornal, na fórmula do discurso de Notícias Populares. O estudo das partes componentes do jornal, que saía com 12 páginas, ajuda a compreender o que os seus criadores definiram como sendo de interesse popular, o lugar do sensacionalismo e a concepção de classes populares que os pautou.

O noticiário do Notícias Populares dividia-se em espaços para políticas nacional, estadual e internacional, temas trabalhistas e sindicais, polícia, esportes e os problemas do cotidiano que afetavam as classes populares. As colunas sociais, faits-divers, vida de artistas, lazer, coluna feminina, horóscopo, turfe, quadrinhos completavam o quadro e buscavam reforçar a atração do público popular. Não havia espaço para editorial, mas as numerosas colunas assinadas, como a "Jean Mellé Informa" ou a "Waldo Claro denuncia", faziam esse papel.

A edição diária de Notícias Populares, entre outubro de 1963 e março de 1964, estava assim organizada:

Capa: mesclava assuntos diversos, da política formal à polícia, além da presença de uma enorme quantidade de fotos, praticamente uma para cada título. A manchete principal variava tematicamente. A partir de dezembro de 1963, a política perdeu espaço na capa para as editorias de polícia e esportes que Mellé acreditava terem maior apelo comercial.

Página 2: era dedicada a assuntos diversos, indo de problemas do cotidiano da cidade de São Paulo a fait-divers, passando por notícias policiais, políticas, econômicas e sindicais. Alguns dos assuntos do dia 6 de dezembro de 1963, nessa página, eram: “Carne: COAP favorece câmbio negro e estabelece a censura"; "Salário deve acompanhar aumento do custo de vida"; "Aluguel de 10 mil poderia subir a 70 mil cruzeiros"; "Encampação ou greve 
geral: operários intimidarão Goulart”; "Menina de dez anos foi degolada num matagal”; "Sarita Montiel estreia amanhã e dia 11 estará em São Paulo”.

Página 3: lugar da coluna "Jean Mellé informa", dedicada a assuntos políticos nacionais e internacionais, tendo como eixo o discurso anticomunista. As matérias que apareciam ao lado dessa coluna também poderiam variar de temática. Assim, no dia 30 de dezembro de 1963, ao lado da coluna de Jean Mellé, que discutia a crise econômica da União Soviética, aparecia matéria com o título "Polícia invadiu 'inferninho japonês': alegria de nisseis terminou na central", que mostra a mistura entre elementos do sensacionalismo e temas políticos contemporâneos, característica do jornal.

Página 4: dedicada à política estadual, e, principalmente, nacional. Nessa seção, as posições da UDN e de Herbert Levy, bem como a batalha para a deslegitimação do PTB e do governo Goulart pautavam o noticiário.

Página 5: era dedicada à política internacional, abordada sob a ótica da Guerra Fria. O jornal posicionava-se na defesa do bloco capitalista, procurava assinalar os conflitos internos e "fracassos" do bloco comunista, denunciando-o como um "regime proscrito". Essa página também contava com notícias sobre a vida privada de celebridades internacionais. Assim, em 5 de novembro de 1963, ao lado da matéria cujo título era "Novo incidente em Berlim gera tensão: 44 americanos detidos pelos soviéticos", aparecia a notícia sobre o casamento da exmulher do Xá da Pérsia: "Xá aprova casamento de Soraya: Maximiliam é um homem sério".

Página 6: dividia o espaço entre a editoria sindical, que abria a página com a seção "São Paulo trabalhista", e a política nacional, por meio das colunas "Waldo Claro denuncia" e "Fábio Mendes: Nossa redação em Brasília". A coluna "Fábio Mendes” fazia a cobertura dos debates no Congresso. Destacava a fala e a ação dos políticos udenistas, principalmente de Herbert Levy, e denunciava as "propostas demagógicas do governo". A coluna "Waldo Claro denuncia" denunciava infiltração comunista nos vários órgãos do governo e em organizações sociais como a União Nacional dos Estudantes (UNE), sindicatos, Ligas Camponesas.

Os temas sindicais, além de terem ocupado quase a página toda, também apareciam espalhados em outras partes do jornal, mostrando que um dos objetivos de Herbert Levy era disputar com a esquerda o setor mais politizado das classes populares. O próprio nome "São Paulo trabalhista" era uma apropriação, por Notícias Populares, do vocabulário do seu oponente: a tradição trabalhista representada principalmente pelo PTB. Uma das estratégias adotadas pelo jornal, a fim de não perder os seus leitores, foi apoiar as reivindicações 
salariais, mas condenar as "greves políticas". Interessante, também, é que, nessa seção, o destaque estava nas mobilizações, encontros sindicais e greves promovidas pelos sindicatos trabalhistas e comunistas, e não do sindicalismo do MSD, como se poderia supor de um jornal cujo proprietário era Herbert Levy. Uma explicação pode estar na própria intensificação da atividade sindical das esquerdas que, naquele contexto, assumiam a ofensiva política ${ }^{47}$.

Entretanto, o MSD aparecia em momentos-chave do discurso do jornal para dar sustentação sindical às ações do grupo de Herbert Levy, ao contrapor a ideia de "trabalhadores" x "subversivos". O exemplo mais forte dessa estratégia se deu após o golpe de 1964, quando o MSD ocupou as páginas de Notícias Populares para defender a repressão aos sindicatos liderados por trabalhistas e comunistas e a prisão de seus líderes. No dia 8 de abril de 1964, Notícias Populares publicava:

\begin{abstract}
"O movimento Sindical Democrático do estado de São Paulo divulgou ontem manifesto enviado às autoridades federais e estaduais assinalando que 'em nome da grande maioria dos trabalhadores paulistas, hipotecamos nosso inteiro apoio ao Congresso Nacional, às Forças Armadas e aos governadores do estado, por terem interpretado positivamente os incontidos anseios do povo paulista em preservar o regime de liberdade, de democracia que estavam ameaçados pela canalha comunista' [...] os trabalhadores democráticos reivindicam das autoridades responsáveis: a) a cassação dos direitos políticos de todos quantos, comprovadamente, no executivo, legislativo federal e estadual vinham facilitando a infiltração comunista, apoiando os vendilhões da pátria; b) expurgo imediato e cassação dos direitos sindicais, nos termos dos dispositivos mencionados, dos dirigentes de confederações e sindicatos comprometidos como comunismo internacional e que eram pagos para conspirar contra os trabalhadores e a nação; c) extinção imediata das organizações comunistas, como o CGT, PAC, FSD [...]" [grifos meus] $^{48}$.
\end{abstract}

Outro ponto a ser ressaltado é que, entre o final de fevereiro e o início de março de 1964, o noticiário sindical praticamente sumiu da página 6. O próprio nome "São Paulo trabalhista", que abria a página, foi extinto. Em seu lugar, foram colocadas notícias policiais, faits-divers e, principalmente, notícias sobre o aumento dos preços dos gêneros alimentícios. A meu ver, as notícias alarmantes sobre a alta dos gêneros alimentícios visavam desestabilizar e retirar o apoio ao Presidente da República, já que afetavam diretamente a vida das classes populares. Ao mesmo tempo, era uma estratégia para silenciar os movimentos sindicais trabalhistas e comunistas quando um golpe de Estado contra João Goulart havia se tornado a primeira opção de Herbert Levy em suas articulações com empresários e militares.

As páginas seguintes eram dedicadas basicamente a entretenimento, incluindo esportes, principalmente futebol, quadrinhos, horóscopo, televisão, e coluna feminina, de 
variedades e social. A página 11 era dedicada à editoria de polícia. Nessa página, tal como em Última Hora, havia espaços para assuntos militares, como a "Coluna Militar" e "Força Pública", que visavam atingir principalmente setores subalternos das Forças Armadas, então em processo de politização. No entanto, o objetivo era esvaziar o caráter político das reivindicações desses setores. Por isso o jornal noticiava apenas promoções e eventos ligados à corporação, como transferências, premiações, além de informar sobre facilitação da compra da casa própria, entre outros. Na contracapa, apenas notícias policiais e de futebol e, raramente, política.

Como visto, embora os diversos temas tivessem espaços mais ou menos cativos, a diagramação não era rígida, podendo aparecer, lado a lado, faits-divers, notícias policiais, econômicas, políticas, sindicais e do cotidiano. Considerando as possíveis limitações do seu público em relação a uma educação formal, a paginação do jornal foi feita de modo acessível, com textos geralmente curtos, manchetes e títulos em letras garrafais e uma enorme quantidade de fotos que, muitas vezes, não condiziam com a importância da matéria.

A linguagem da abordagem dos temas era diversa. Assim, nas editorias de polícia, de esporte e de cotidiano, recorria-se à linguagem sensacionalista. Já nas editorias política e sindical, embora não excluísse recursos do sensacionalismo, predominou uma linguagem mais formal - exceto nas manchetes e títulos. No entanto, também essa divisão não era rígida.

Para conquistar o leitor popular, o jornal também dava ampla cobertura para problemas do cotidiano, com o a questão do tabelamento do preço dos gêneros de primeira necessidade ou dos alugueis, sempre com alarde, insinuando uma situação de caos no país. A cobertura econômica do Notícias Populares, diferente da cobertura política, tendia a se restringir ao universo dos problemas do cotidiano popular. Entre os dias 18 e 30 de outubro de 1963, por exemplo, o jornal, diariamente, noticiou o locaute dos açougueiros contra o tabelamento do preço da carne pela Sunab. O título principal da segunda página, no dia 16 de outubro, era: "Açougueiros vencem a parada. Demitido presidente da COAP". Com essa pauta firmemente ancorada nos interesses da população, associada a esporte, entretenimento, notícias policiais, o jornal buscava construir seu vínculo com os leitores.

Como destaca Goldenstein, no início, Notícias Populares era parecido com Última Hora. Sua diagramação era semelhante, especialmente na capa, onde conviviam diversos assuntos em chamadas, manchetes em letras garrafais, muitas fotos, especialmente de crimes, tragédias e mulheres bonitas. Notícias Populares também aproveitou de Última Hora o formato das editorias de cidades, política, esportes e sindical e as notas sociais de clubes 
populares, apresentando-se, no entanto, como uma versão mais pobre desse jornal e não só no número de páginas - Notícias Populares saía com 12 páginas contra 24 do Última Hora. Enquanto Última Hora apresentava, ao lado das matérias de promoção dos artistas e de shows, colunas de crítica literária, cinema, artes plásticas, Notícias Populares só tinha o primeiro tipo de matéria: fofocas, promoção de artistas e espetáculo ${ }^{49}$. Outra diferença é que Notícias Populares não fez uso de espaços de comunicação com os leitores como a "tendinha das reclamações" ou a seção de cartas dos leitores, que, em Última Hora, eram instrumentos fundamentais para o jornal construir a imagem de intermediário entre povo e governo.

\section{Tensões e ambiguidades na visão de povo}

Ao analisarmos a organização interna do conteúdo, a diagramação e a linguagem dos temas, percebemos que Notícias Populares trabalhava com uma visão ambígua das classes populares: ora um povo despreparado, despolitizado, interessado apenas no trio "sexo, crime, esportes"; ora sujeito político, ativo nas esferas de participação da política. No entanto, mesmo essa imagem do povo como sujeito político foi construída sob tensão, como nos revela a abordagem do tema do sindicalismo.

O movimento sindical foi um dos grandes temas abordados por Notícias Populares, exatamente por ser o sindicato, naquele contexto, tanto o lugar por onde os trabalhadores se politizavam e se mobilizavam, quanto por ser uma das bases do governo Goulart, que tratava os líderes sindicais como interlocutores privilegiados, conforme mostra Gomes ${ }^{50}$.

A análise que Notícias Populares fez da greve geral dos 700 mil, ocorrida em São Paulo entre outubro e novembro de 1963, permite vislumbrar as ambiguidades na visão do povo como sujeito político divulgadas pelo jornal. Desde 18 de outubro de 1963, 11 dias antes da eclosão da greve, o jornal vinha noticiando as tensões entre os trabalhadores de vários ramos da indústria de São Paulo, representados pelo Pacto de Ação Conjunta (PAC), intersindical ligada ao Comando Geral dos Trabalhadores (CGT), de orientação de esquerda, e pela Confederação Nacional dos Trabalhadores da Indústria (CNTI), então nas mãos do PTB$\mathrm{PCB}^{51}$. Sob o título "Aumento para os industriários: guerra fria pode pegar fogo", o jornal anunciava o conflito entre o PAC, e depois a CNTI, representando 79 sindicatos, e os empresários representados pela Fiesp.

Quando da eclosão da greve geral, marcada por forte mobilização e participação dos trabalhadores, o jornal mudou o tom e buscou reverter a situação. No dia 29 de outubro de 1963, toda a primeira página, cuja manchete era “Greve estourou!”, e que tinha como um dos 
títulos "Fiesp não reconhece ditadura sindical", foi dedicada ao tema da greve. Um dos pontos mais ressaltados foi a questão da ilegitimidade da greve, já que seria "política" e liderada por "elementos subversivos" e "líderes sindicais pelegos". Esse discurso se repetiu em vários espaços do jornal, como na coluna "Waldo Claro denuncia":

\begin{abstract}
"São Paulo pode amanhecer paralisado por uma greve completamente espúria, no sentido de dar continuidade ao esquema acionado pelo governo federal [...] aos seus desejos confessos de continuísmo [...]Setecentos mil trabalhadores, segundo o IBGE do CGT, deixarão de cumprir com seu dever perante a pátria e perante as necessidades de suas famílias. Seguirão pelo caminho de dubiedades, para obedecerem simplesmente e passivamente os que fizeram do instituto da greve, a indústria para um enriquecimento fácil e sem grandeza. [...] a hora não é de seguir os pelegos amestrados em Havana, é de continuar seguindo pela trilha brasileira, que é nossa e é cristão [...] [grifos meus] $]^{52}$.
\end{abstract}

No texto acima, a participação do trabalhador na greve foi explicada pela manipulação do governo federal com vistas a seu projeto continuísta, e dos "pelegos comunistas" do CGT. No discurso de Waldo Claro, os sindicatos e a greve perderam a sua legitimidade por serem órgãos cooptados por líderes "corruptos e pelegos", que não representavam verdadeiramente os trabalhadores e que os estariam usando para atingir objetivos políticos, alheios ao que o jornal entendia como sendo as reivindicações da categoria. Assim, o trabalhador, que “obedece simplesmente e passivamente", perdeu, no discurso do jornal, a sua condição de sujeito político, de indivíduo livre e autônomo com capacidade para tomar suas próprias decisões e agir politicamente. Para anular a mobilização dos trabalhadores, o jornal desqualificou o espaço (sindicato) e o momento (greve) de ação política dos trabalhadores e definiu um lugar social para o operário: zelar pela pátria e por sua família através da sua produção. Vale destacar que, nesse ponto, Notícias Populares fazia coro com o discurso das lideranças industriais paulistas para as quais os sindicatos teriam uma participação construtiva nas relações de trabalho e no fomento da paz social desde que não se tornassem veículos de agitação extremista ao incentivar greves ou outros obstáculos para a produtividade ${ }^{53}$. Ao considerar a ação política da classe trabalhadora como fruto da manipulação, Notícias Populares negou-se, ainda, a reconhecer uma relação de reciprocidade, mesmo que assimétrica, entre Estado e classes trabalhadoras, já que o trabalhador seria apenas uma vítima das maquinações do Estado e dos grupos de esquerda.

Em continuidade a essa linha de argumentação, no dia 31 de outubro de 1963, o jornal publicou, quase na íntegra, a resposta de Herbert Levy a Almino Afonso, do PTB, sobre a 
greve geral em São Paulo. Sob o título “Levy adverte aos intervencionistas: São Paulo pegará em armas", o jornal fez das palavras de Levy a sua posição:

[...] a extrema esquerda foi reduzida na sua expressão eleitoral e política. Isto demonstrou [...] a saturação em que se encontram os verdadeiros trabalhadores esses que não são pelegos, esses que não são líderes da extrema esquerda a serviço de ideologias exóticas; demonstrou como a maioria absoluta de trabalhadores está cansada de ser explorada, na forma de greves políticas que não encontram acolhidas na constituição [...] é porque o partido de V. Excia. [...] está fracassando, não interpreta mais os sentimentos dos trabalhadores [...] enquanto em São Paulo há ordem, trabalho e, como aqui se diz, mais de $70 \%$ dos trabalhadores não querem ouvir falar em greve, em Pernambuco, através de impressionantes relatórios das classes produtoras [...] o que se verifica é a comunização $[\ldots]^{54}$.

Novamente aqui se contrapôs o trabalhador ao grevista e ao líder sindical "que buscavam subverter as relações político-sociais no Brasil”. No mesmo movimento, a matéria buscou deslegitimar o PTB, partido mais popular no período, enquanto representante dos trabalhadores. Mas, diferente do texto de Waldo Claro, o que se ressaltou na comunicação de Levy foi a contraposição da imagem da ordem em São Paulo, onde os trabalhadores não aderem a ideologias exóticas, à comunização, portanto, à desordem, em Pernambuco, de Miguel Arraes, importante líder das esquerdas. Dessa forma, o mito da índole cordial e pacífica do povo brasileiro, que o comunista queria corromper, era acionado para deslegitimar o movimento dos trabalhadores. Na reportagem, o jornal ainda deixava claro que Levy encarava todas as greves reivindicatórias como legítimas, não lhes fazendo restrição. $\mathrm{O}$ problema estava no fato de elas serem manipuladas por elementos exteriores ao operariado. Esse foi o discurso predominante do jornal nas abordagens de praticamente todas as greves. As reivindicações salariais eram reconhecidas - afinal, o jornal não poderia perder a interlocução com o seu público -, mas a participação política dos trabalhadores, quando envolvia sindicatos à esquerda, era vedada sob a acusação de manipulação dos trabalhadores.

Dessa forma, Notícias Populares construiu um discurso que definia os limites do comportamento político da classe trabalhadora ao articular o reconhecimento dessa classe como ator político e a disputa pelo seu apoio, visto como inevitável naquela conjuntura política, e o controle dessas classes. O lugar da cidadania para as classes populares, na visão do jornal, estava no trabalho, ou na ação política desde que fosse contrária ao governo Goulart e às esquerdas - daí todo o investimento de Levy em fundar sindicatos anticomunistas ou de conclamar, pelo jornal, as classes populares a comparecerem às ações contra João Goulart. 


\section{Considerações finais}

A análise do processo de criação e montagem do jornal Notícias Populares, articulado à visão de povo e de jornal popular que pautou seus criadores, permitiu reavaliar intepretações que apontam a função despolitizadora do jornal, bem como pensar o lugar atribuído às classes populares, pelos setores representados por Herbert Levy, no processo político brasileiro do início da década de 1960.

Trabalhei com a ideia de que um conjunto de eventos ocorridos nos primeiros anos da década, sustentados por ampla campanha popular - a luta pela posse de Goulart (1961), o crescimento eleitoral do PTB (1962) e a vitória do presidencialismo (1963)-, serviu de pedagogia política para o grupo de Herbert Levy. Tomados como derrotas políticas, tais fatos foram atribuídos, em parte, às mobilizações favoráveis a João Goulart, o que evidenciou a necessidade de ampliar a base de apoio popular aos setores de oposição ao governo. As classes populares foram reconhecidas pelos setores representados por Levy como atores estratégicos que precisavam ser conquistados, mesmo que esse reconhecimento tenha sido feito sob tensões e ambiguidades.

A ênfase dada pelo jornal ao noticiário político, que chegou a ocupar metade das matérias redacionais, e o forte empenho em formular um discurso anti-Goulart e anticomunista, paralelamente à promoção política da figura de Herbert Levy, bem como das posições políticas da UDN, revelou como o apoio das classes populares foi percebido como um ponto de não retorno. A partir daquele momento seria imprescindível para as ações contra o governo.

Mas esse reconhecimento não foi feito sem tensões, já que a ação política das classes populares, consideradas carentes de qualificação cultural, era atribuída à manipulação de Goulart e dos grupos de esquerda. Daí a ambiguidade no tratamento do povo como sujeito político. Notícias Populares construiu um discurso que definia os limites do comportamento político das classes populares. O lugar da cidadania dessas classes estaria no trabalho ou em uma ação política limitada aos "valores cristãos e democráticos", ou seja, desde que estivessem alinhadas aos valores dos setores representados por Herbert Levy.

Com o golpe em 1964, as classes populares foram neutralizadas e as esquerdas reprimidas. Com seu objetivo político concretizado, Herbert Levy perdeu o interesse pelo jornal. Outro motivo para o seu desinteresse, provavelmente, foi a frustração de sua candidatura às eleições a governador de São Paulo, que deveriam ocorrer em 1966 e que foram suspensas pelo regime militar. Levy era o nome da UDN para essas eleições, o que 
contribuía para o seu interesse por Notícias Populares. Entretanto, o seu nome foi preterido pelos militares em favor de Paulo Egídio Martins. Em 1965, Herbert Levy vendeu Notícias Populares para o Grupo Folha da Manhã, de Otávio Frias de Oliveira e Carlos Caldeira Filho, que também comprou o jornal Última Hora, de Samuel Wainer. Afinal, não havia mais motivos para que os dois jornais se apresentassem em campos opostos. Notícias Populares foi publicado pelo Grupo Folha de 1965 a 2001. Nesse período, ele ficou conhecido como um jornal predominantemente sensacionalista, aquele que "espreme e sai sangue".

\section{Notas}

\footnotetext{
${ }^{1}$ Seguindo a caracterização feita por Weffort, as expressões povo e classes populares são usadas aqui como sinônimos não só de classe operária, mas também em seu componente urbano, das camadas inferiores de assalariados não industriais e trabalhadores autônomos. WEFFORT, Francisco. O populismo na política brasileira. Rio de Janeiro: Paz e Terra, 1978, p.72.

${ }^{2}$ GOLDENSTEIN, Gisela Taschner. Do jornalismo político à indústria cultural. São Paulo: Summus,1987, p.77-94.

${ }^{3}$ Ibidem

${ }^{4}$ RÉMOND, René. Do Político. In RÉMOND, René (Org). Por uma história Política. 2.ed. Rio de Janeiro: FGV, 2003, p. 441.

${ }^{5}$ LUCA, Tânia Regina de. História dos, nos e por meio dos periódicos. In PINSKY, Carla Bassanezi (org). Fontes históricas. São Paulo: Contexto,2008, p.138.

${ }^{6}$ CAMPOS JR, Celso de et al. Nada Mais que a verdade. A extraordinária história do jornal Notícias Populares. São Paulo: Carrenho Editorial, 2002, p. 34-40.

${ }^{7}$ Ibidem.

${ }^{8}$ Sobre a atuação política de Herbert Levy ao longo do governo João Goulart (1961-1964), ver CESTARI, Larissa Raele. A conquista do povo: Notícias Populares e a oposição ao governo João Goulart. Dissertação (Mestrado em História, Política e Bens Culturais)- Centro de Pesquisa e documentação de História Contemporânea da Fundação Getúlio Vargas (FGV-CPDOC). Rio de Janeiro, 2013, cap.1.

${ }^{9}$ BENEVIDES, Maria Victoria de Mesquita. A UDN e o udenismo. Ambigüidades do liberalismo brasileiro (1945-1965). Rio de Janeiro: Paz e Terra, 1981, p. 181.

${ }^{10}$ Ver CAMPOS JR et al., op. cit..

${ }^{11}$ SIQUEIRA, Carla Vieira de. "Sexo, Crime e Sindicato": Sensacionalismo e populismo nos jornais Última Hora, O Dia e Luta Democrática durante o segundo governo Vargas (1951-1954). Tese (Doutorado em História)- Pontifícia Universidade Católica (PUC). Rio de Janeiro, 2002, p.143.

${ }^{12}$ GOLDENSTEIN, op. cit., p. 43-49.

${ }^{13}$ BENEVIDES, Maria Victoria de Mesquita. O PTB e o trabalhismo. Partido e sindicato em São Paulo (19451964). São Paulo: BrasilienselCedec, 1989.

${ }^{14}$ GOLDENSTEIN, op. cit.; CAMPOS JR et al., op. cit.; WAINER, Samuel. Minha razão de viver. Rio de Janeiro, Record, 1987.

${ }^{15}$ WAINER, op. cit., p. 249.

${ }^{16}$ POVO unido conquistará reformas. Última Hora, Rio de Janeiro, p.2, 1 nov. 1963.

${ }^{17}$ CONSTITUIÇÃO está superada. Última Hora, Rio de Janeiro, p. 2, 1 nov. 1963.

${ }^{18}$ LEVY, Herbert. Viver é lutar. São Paulo: Saraiva, 1990, p. 111.

${ }^{19}$ Sobre a crise política aberta após a renúncia de Jânio Quadros (1961), ver as análises de FIGUEIREDO, Argelina. Democracia ou reformas? Alternativas democráticas à crise política:1961-1964. São Paulo: Paz e Terra, 1993; FERREIRA, Jorge. O governo Goulart e o golpe civil-militar de 1964. In FERREIRA, Jorge; DELAGADO, Lucilia de Almeida. O Brasil Republicano. O tempo da experiênica democrática. Da democratização de 1945 ao golpe civil-militar de 1964. Rio de Janeiro: Civilização Brasileira, 2003.

${ }^{20}$ GOLDENSTEIN, op. cit., p. 77-79.
} 
${ }^{21}$ Ibidem.

${ }^{22}$ Ibidem, p. 79.

${ }^{23}$ Ibidem, p. 80.

${ }^{24}$ LEVY, op. cit., p. 111. Sobre o papel da grande imprensa na campanha contra o governo João Goulart, ver ABREU, Alzira Alves de. 1964: a imprensa ajudou a derrubar o governo Goulart. In: FERREIRA, Marieta de Moraes. João Goulart: entre a memória e a história. Rio de Janeiro: FGV, 2006; CARVALHO, Aloysio Castelo de. A Rede da Democracia: O Globo, O Jornal e o Jornal do Brasil na queda do governo Goulart (1961-1964). Niterói: Editora UFF, Editora NitPress, 2010.

${ }^{25}$ GOLDENSTEIN, op. cit., p.95-135.

26 Ibidem, p.84.

${ }^{27}$ Ibidem, p. 87.

${ }^{28}$ CAMPOS JR et al., op. cit., p.53- 66.

${ }^{29}$ GOLDENSTEIN, op. cit., p.35.

${ }^{30}$ LAVAREDA, José Antonio. A democracia nas urnas: o processo partidário eleitoral brasileiro. Rio de Janeiro: fundolIuperj, 1991, p. 137.

${ }^{31}$ CAMPOS JR et al., op. cit., p. 47.

${ }^{32}$ GOLDENSTEIN, op. cit..

${ }^{33}$ Ibidem, p. 83.

${ }^{34}$ Ibidem, p.77-87.

${ }^{35}$ Ver CESTARI, op. cit., cap. 1 e 2.

${ }^{36}$ LEVY: Jango atrasa mínimo para fazer revolução. Notícias Populares, São Paulo, p.6, 19 fev. 1964.

37 LEVY: nenhum acordo com Goulart. Notícias Populares, São Paulo, p. 4, 18 out. 1963.

38 MENDES, Fábio. Fábio Mendes: nossa redação em Brasília. Notícias Populares, São Paulo, p. 6, 19 nov.1963.

${ }^{39}$ INQUILINATO, salário móvel e 13 para funcionários. Última Hora, Rio de Janeiro, p.4, 2 dez. 1963.

${ }^{40}$ FICO, Carlos. Além do golpe. Versões e Controvérsias sobre 1964 e a ditadura. Rio de Janeiro: Record, 2004, p.76.

${ }^{41}$ MOTTA, Rodrigo Patto Sá. Em guarda contra o "perigo vermelho": o anticomunismo no Brasil (19171964). São Paulo: Perspectiva: FAPESP, 2002.

${ }^{42}$ Ver CESTARI, op. cit., cap. 3; Cestari, Larissa Raele. A pedagogia política anticomunista no jornal "Notícias Populares” (1963-1964). Revista Brasileira de História da Mídia (RBHM), V.2, n.1, jan. 2013ljun. 2013. P. 6169.

${ }^{43}$ MENDES, Fábio. Fábio Mendes: nossa redação em Brasília. Notícias Populares, São Paulo, p. 6, 19 nov.1963.

${ }^{44}$ GOLDENSTEIN, op. cit..

${ }^{45}$ BARBOSA, Marialva. Jornalismo popular e o sensacionalismo. Verso e Reverso. Porto Alegre, v.39, n³9, 2004.

${ }^{46}$ Para uma discussão sobre o sensacionalismo e o jornalismo popular, ver também AMARAL, Márcia Franz. Jornalismo Popular. São Paulo: Contexto, 2006; SIQUEIRA, op. cit. Sobre o sensacionalismo no jornal Notícias Populares, ver ANGRIMANI, Danilo. Espreme que sai sangue: um estudo do sensacionalismo na imprensa. São Paulo: Summus, 1995; PROENÇA, José Luis. O jornalismo envergonhado: a idealização do leitor no jornal Notícias Populares. Dissertação (Mestrado em Ciências da Comunicação). Escola de Comunicação e Artes, Universidade de São Paulo. São Paulo, 1992.

47 DELGADO, Lucilia de Almeida Neves. O comando Geral dos trabalhadores no Brasil:1961-1964. Petrópolis: Vozes, 1986; NEGRO, Antonio Luigi; SILVA, Fernando Teixeira da. Trabalhadores, sindicatos e política (1945-1964). In: FERREIRA, Jorge; DELGADO, Lucilia de Almeida Neves. O Brasil Republicano. O tempo da experiência democrática. Da democratização de 1945 ao golpe civil-militar de 1964. Rio de Janeiro: Civilização Brasileira, 2003; SANTANA, Marco Aurélio. Bravos companheiros: a aliança comunista trabalhista no sindicalismo brasileiro (1945-1964). In: FERREIRA, Jorge; REIS FILHO, Daniel Aarão. Nacionalismo e reformismo radical (1945-1964). Rio de Janeiro: Civilização Brasileira, 2007.

${ }^{48}$ MOVIMENTO Sindical Democrático. Notícias Populares, São Paulo, p.6, 8 abr. 1964.

${ }^{49}$ GOLDENSTEIN, op. cit., p. 92.

${ }^{50}$ GOMES, Angela de Castro. Memórias em disputa: Jango, ministro do trabalho ou dos trabalhadores? In: FERREIRA, Marieta de Moraes. João Goulart: entre a memória e a história. Rio de Janeiro: FGV, 2006.

${ }^{51}$ NEGRO; SILVA, op. cit., p.3.

${ }^{52}$ CLARO, Waldo. Waldo Claro denuncia. Notícias Populares, São Paulo, p.6, 29 out. 1963.

53 WEINSTEIN, Barbara. (Re)formação da classe trabalhadora no Brasil (1920-1964). São Paulo: Cortezl CDAPH-IFAN - Universidade São Francisco, 2000. 
${ }^{54}$ LEVY adverte aos intervencionistas: São Paulo pegará em armas. Notícias Populares, São Paulo, p. 3, 31 out. 1963.

\section{Referências}

ANGRIMANI, Danilo. Espreme que sai sangue: um estudo do sensacionalismo na imprensa. São Paulo: Summus, 1995.

ABREU, Alzira Alves de. 1964: a imprensa ajudou a derrubar o governo Goulart. In FERREIRA, Marieta de Moraes. João Goulart: entre a memória e a história. Rio de Janeiro:FGV, 2006.

AMARAL, Márcia Franz. Jornalismo Popular. São Paulo: Contexto, 2006.

BARBOSA, Marialva. Jornalismo popular e o sensacionalismo. Verso e Reverso. Porto Alegre, v.39, n³9, 2004.

BENEVIDES, Maria Victoria de Mesquita. A UDN e o udenismo. Ambigüidades do liberalismo brasileiro (1945-1965). Rio de Janeiro: Paz e Terra, 1981.

BENEVIDES, Maria Victoria de Mesquita. O PTB e o trabalhismo. Partido e sindicato em São Paulo (1945-1964). São Paulo: BrasilienselCedec, 1989.

CAMPOS JR, Celso de et al. Nada Mais que a verdade. A extraordinária história do jornal Notícias Populares. São Paulo: Carrenho Editorial, 2002.

CARVALHO, Aloysio Castelo de. A Rede da Democracia: O Globo, O Jornal e o Jornal do Brasil na queda do governo Goulart (1961-1964). Niterói: Editora UFF, Editora NitPress, 2010.

CESTARI, Larissa Raele. A conquista do povo: Notícias Populares e a oposição ao governo João Goulart. Dissertação (Mestrado em História, Política e Bens Culturais)- Centro de Pesquisa e documentação de História Contemporânea da Fundação Getúlio Vargas (FGVCPDOC). Rio de Janeiro, 2013.

Cestari, Larissa Raele. A pedagogia política anticomunista no jornal "Notícias Populares" (1963-1964). Revista Brasileira de História da Mídia (RBHM), V.2, n.1, jan. 2013 jun. 2013, P. 61-69.

Cestari, Larissa Raele. As visões de povo no jornal "Notícias Populares" e no conceito de populismo. História e Cultura, v.7, n.2, 2018.

CLARO, Waldo. Waldo Claro denuncia. Notícias Populares, São Paulo, p. 6, 29 out. 1963.

DELGADO, Lucilia de Almeida Neves. O comando Geral dos trabalhadores no Brasil:19611964. Petrópolis: Vozes, 1986. 
FERREIRA, Jorge. O governo Goulart e o golpe civil-militar de 1964. In: FERREIRA, Jorge; DELAGADO, Lucilia de Almeida. O Brasil Republicano. O tempo da experiênica democrática. Da democratização de 1945 ao golpe civil-militar de 1964. Rio de Janeiro: Civilização Brasileira, 2003.

FERREIRA, Jorge. A estratégia do confronto: a Frente de Mobilização Popular. Revista Brasileira de História. São Paulo:Anpuh, vol.24, n.47, jan - jun, 2004, p.181-212.

FICO, Carlos. Além do golpe. Versões e Controvérsias sobre 1964 e a ditadura. Rio de Janeiro:Record, 2004.

FIGUEIREDO, Argelina. Democracia ou reformas? Alternativas democráticas à crise política:1961-1964. São Paulo: Paz e Terra, 1993.

GOLDENSTEIN, Gisela Taschner. Do jornalismo político à indústria cultural. São Paulo:Summus, 1987.

GOMES, Angela de Castro. Memórias em disputa: Jango, ministro do trabalho ou dos trabalhadores? In: Ferreira, Marieta de Moraes. João Goulart: entre a memória e a história. Rio de Janeiro: FGV, 2006.

INQUILINATO, salário móvel e 13 para funcionários. Última Hora, Rio de Janeiro, 2 dez. 1963, p.4.

LAVAREDA, José Antonio. A democracia nas urnas: o processo partidário eleitoral brasileiro. Rio de Janeiro: fundoluperj, 1991.

LEVY, Herbert. Viver é lutar. São Paulo: Saraiva, 1990.

LEVY adverte aos intervencionistas: São Paulo pegará em armas. Notícias Populares, São Paulo, 31 out. 1963, p. 3.

LUCA, Tânia Regina de. História dos, nos e por meio dos periódicos. In PINSKY, Carla Bassanezi (org). Fontes históricas. São Paulo:Contexto,2008.

MENDES, Fábio. Fábio Mendes: nossa redação em Brasília. Notícias Populares, São Paulo, 19 nov.1963, p.6.

MOTTA, Rodrigo Patto Sá. Em guarda contra o "perigo vermelho": o anticomunismo no Brasil (1917- 1964). São Paulo: Perspectiva: FAPESP,2002.

MOVIMENTO Sindical Democrático. Notícias Populares, São Paulo, p.6, 8 abr. 1964.

NEGRO, Antonio Luigi; SILVA, Fernando Teixeira da. Trabalhadores, sindicatos e política (1945-1964). In FERREIRA, Jorge; DELGADO, Lucilia de Almeida Neves. O Brasil Republicano. O tempo da experiência democrática. Da democratização de 1945 ao golpe civil-militar de 1964. Rio de Janeiro: Civilização Brasileira, 2003. 
PROENÇA, José Luis. O jornalismo envergonhado: a idealização do leitor no jornal Notícias Populares. São Paulo, 1992. Dissertação (Mestrado em Ciências da Comunicação). Escola de Comunicação e Artes, Universidade de São Paulo.

RÉMOND, René. Do Político. In RÉMOND, René (Org). Por uma história Política. 2.ed. Rio de Janeiro: FGV, 2003.

RÉMOND, René. Uma história presente. In RÉMOND, René (Org). Por uma história Política. 2.ed. Rio de Janeiro: FGV, 2003.

SANTANA, Marco Aurélio. Bravos companheiros: a aliança comunista - trabalhista no sindicalismo brasileiro (1945-1964). In: FERREIRA, Jorge; REIS FILHO, Daniel Aarão. Nacionalismo e reformismo radical (1945-1964). Rio de Janeiro: Civilização Brasileira, 2007.

SILVA, Fernando Teixeira; NEGRO, Antonio Luigi. "Trabalhadores, sindicato e política (1945-1964)". In: FERREIRA, Jorge; DELGADO, Lucilia de Almeira Neves. O Brasil Republicano. O tempo da experiência democrática. Da democratização de 1945 ao golpe civil- militar de 1964. Rio de janeiro: Civilização Brasileira, 2003.

SIQUEIRA, Carla Vieira de. "Sexo, Crime e Sindicato": Sensacionalismo e populismo nos jornais Última Hora, O Dia e Luta Democrática durante o segundo governo Vargas (19511954). Tese (Doutorado em História)- Departamento de História, Pontifícia Universidade Católica do Rio de Janeiro. Rio de Janeiro, 2002.

WAINER, Samuel. Minha razão de viver. Rio de Janeiro, Record, 1987.

WEFFORT, Francisco. O populismo na política brasileira. Rio de Janeiro, Paz e Terra, 1978.

WEINSTEIN, Barbara. (Re)formação da classe trabalhadora no Brasil (1920-1964). São Paulo: Cortez\ CDAPH-IFAN - Universidade São Francisco, 2000. 